Faculty of Law, University of Priština,

Temporary Head Office in Kosovska Mitrovica

UDK: 347.778:602.9

602.9:172

Рад примљен: 30.09.2020.

Рад прихваћен: 08.12.2020.

\title{
PROS AND CONS OF PATENTING STEM CELLS
}

\begin{abstract}
The evolution and transformation of research in the field of biotechnology are clearly reflected in patent rules. In view of further development of biotechnology and the pressure from multinational biotechnical companies, gene patenting was first granted in some legal systems in order to initiate the regulation of patent protection of stem cells. Further research should provide a better understanding of the differentiation and development of stem cells, including their potential effects in curing previously incurable diseases. It should also engender new ways of exploring fundamental issues in biology, such as the mechanism of cell growth. Therefore, researchers and primarily biotech companies advocate in favor of ensuring the monopoly on the results of their research. Such a monopoly is secured by patent law. Although remarkable progress has been made in the research of stem cells, many aspects of their use, especially of embryonic cells, have not been fully clarified and made comprehensible. Successful applications of products that use a stem cell derivative (on the one hand) and moral dilemmas primarily relating to embryonic stem cells (on the other hand) have resulted in a debate that has affected many legal areas, such as patent law. Such morally challenging products have caused great concern in the USA and the EU. However, these two entities have tried to solve the problem in different ways. Different views on law, ethics and embryos have also affected different views regarding patent protection of stem cells.
\end{abstract}

Keywords: biotechnology, inventions, patents, genes, stem cells.

*gordana.damjanovic@pr.ac.rs 


\section{Introduction}

In the area of patent law, not many questions are as complex as the question of biotechnological invention protection in general, and the question of stem cell protection in particular. No biotechnological invention has spurred so much discussion and different legal views as the issue of stem cell legal protection. In terms of biotechnological inventions, most difficulties have been encountered by patent offices and courts due to the need to react promptly to frequent changes, to empower expertise within institutions, to evaluate the state of technology, and to determine the correct standard for broadness of granted patents.

Stem or pluripotent cells were first isolated from a human embryo in the blastocyst stadium by the researchers at the University of Wisconsin in the USA (in 1998). The human embryo was cloned for the first time in November 1998, at the ACT (Advanced Cell Technology) Institution. An embryo was disrupted in its growth in the blastocyst stage in order to obtain stem cells from it and to develop cell threads such as nerve cells, bone marrow cells, muscle, or blood cells could be developed. In the scientific view, the most important notion is that stem cells could grow and differentiate in any type of cell in the human body. These characteristics provide massive potential in studying and treating serious illnesses like Alzheimer's or Parkinson's Disease, as well as diabetes. The potentials of stem cells are practically unlimited because they can induce organ regeneration or regeneration of the damaged immune system. It should be emphasized though that stem cell research is still in its infancy and that scientists seek a better understanding of the role of stem cells in normal human development and disease development.

Further research should provide a better understanding of differentiation and stem cell development along with their potential effects in curing incurable diseases. It should also engender new research methods for exploring fundamental questions in biology, such as the cell growth mechanism. Therapeutic potentials of both embryonic and "mature" stem cells are huge, but so are resources invested in their research. For this reason, all researchers, primarily big biotechnological companies, advocate for acquiring a monopoly over their research results. Such a monopoly is secured by patent law.

\section{The notion of stem cells}

\subsection{Stem cell development and types of stem cells}

Scientists in the field of medicine claim that stem cells are the foundation of the development of the entire human organism. Millions of cells of more than two hundred types are involved in the creation of the human organism, and every 
one of them has its specific function; stem cells are specialized and, as such, they hold the potential to develop in one or multiple types of cells.

If we look at the creation of the human organism from the perspective of biology, we learn that the organism evolves through a certain number of successive phases. At the moment of fertilization, there is only one cell - a zygote (fertilized egg), and that cell divides very rapidly in the first couple of days. In that phase, the zygote consists of totipotent stem cells. The cell's ability to proliferate and to create daughter cells, which can then be of any cell type, is called cell potency. The totipotent cells hold the greatest development potential: they can transform into any cell type in the human organism, and they can develop into a separate embryo as well. Therefore, every totipotent cell represents an independent entity that can evolve into an entire organism (Mitalipov, Wolf, 2009:199). However, within five to seven days, the organism turns into a blastocyst, a ball of few hundred stem cells that are no longer totipotent, but pluripotent. Those cells can develop into any out of two hundred cell types within the organism, but they are no longer able to develop into an embryo (Радоњанин, 2007: 4).

Pluripotency means having more than one potential outcome. Pluripotent cells can reach the fetus or a certain cell stage, but an individual or the conglomerate of pluripotent cells cannot develop into a fetus because they lack the potential to grow into an embryo. As the development of the embryo continues, its cells become differentiated and take over a certain role in the human organism. From that moment on, the embryo is called a fetus while stem cells become multipotent (Laurie, 2004: 3). Multipotent cells are those that can transform into a smaller number of different cell types. Multipotent stem cells are a few non-differentiated cells in the tissue of developed organisms that can differentiate into closely related cells. For example, they can develop into different types of blood cells, but never into a muscle or some other cells. Finally, stem cells can be unipotent when only one type of cells can grow out of them, and they differ from non-stem cells by the ability to self-regenerate. Unipotent or oligopotent stem cells can only differentiate into one type of cell, such as cardio-vascular or skin cells, deserving of tissue regeneration (Zhu, 2011: 13). This ability to regenerate the damaged tissue makes those cells unique in medicine. They serve as a kind of internal repair system in numerous tissue types.

Stem cell research will enable scientists to learn more about basic cell characteristics and what makes them different from specialized cell types. Considering that they have unique regenerative abilities, stem cells offer new possibilities for treating diseases like diabetes and different heart diseases. One of the main characteristics of stem cells is self-regeneration, which implies a cell's ability to go through multiple division cycles while remaining undifferentiated into 
specialized cell types. ${ }^{1}$ Under certain physiological or experimental conditions, stem cells may be prompted to become tissue or specialized cells with specific functions. In certain organs, like the intestine or bone marrow, stem cells divide regularly by substituting old cells or damaged tissue, while in organs such as the pancreas and heart the division is possible under certain conditions. Thanks to these characteristics, they substitute dying cells and regenerate damaged tissue. The possibility of tissue substitution based on stem cell treatment is successfully promoted world-wide. The diseases treated in this manner are leukemia, lymphoma, and some other. At this point, some treatments are clinically tested; generally, clinical test results show that stem cell treatment is effective but still not accepted as a standard. Doctors believe that many diseases, like diabetes or nervous system illnesses, will be treated with stem cells only in a few years' time. Besides being characterized by the ability to reproduce without a time limit, stem cells are also reversible. Reversibility is the ability of certain stem cells to return to their previous state, which practically means that embryonic stem cells can regress to the embryonal phase and become embryos.

There are four types of stem cells: 1) embryonic stem cells from the blastocyst stadium of embryo development; 2) mature stem cells which all organs are made of; 3) stem cells in the umbilical cord; and, 4) induced pluripotent cells - mature cells, genetically reprogrammed into stem cells (like embryonic stem cells). ${ }^{2}$

\subsection{Stem cells as an invention of a product and a method}

Careful research of different invention patent applications shows that patent protection has been approved for inventions and applications in the entire sector of human stem cell research. Patents are so issued for inventions in the areas of pluripotent embryonic stem cells, multipotent mature stem cells, as well as multipotent mature stem cells of the fetus. Before establishing a moratorium on stem cell patents in Europe (Case 112/11 Oliver Brustle v Greenpeace e V

1 For more on types of stem cells, see: https://www.seracell.rs/maticne-celije/tipovimaticnih-celija, 25.08.2020.

2 Embryonic stem cells and induced pluripotent cells are very similar; in controlled environments, both of them can grow into any kind of cell. They can self-regenerate, they can divide and produce their copies indefinitely. Unlike embryonic stem cells, induced pluripotent cells do not cause the destruction of an embryo. Yet, the results of recent research show that certain genes in induced pluripotent stem cells behave a bit differently than the genes of embryonic stem cells; that means that it is too risky to substitute embryonic stem cells with induced pluripotent stem cells in basic research at this point. See: DW (2015): Regenerativna medicina - nada za mnoge, by G. Hajze, 22.10.2015, https://www.dw.com/sr/regenerativnamedicina-nada-za-mnoge/a-18799514, accessed 24.06.2020. 
language Europa $E U(2011)^{3}$, based on the analysis of reported and approved patents related to all types of stem cells both in Europe and in the USA, it can be concluded that patenting biological material taken from the human body became usual practice on both continents. Numerous patents related to mature stem cells have been approved. Of course, the situation is very different in terms of embryonic stem cells.

Stem cell patents can be approved both as a product and a method. The first patent related to human embryonic stem cells (approved by the United States Patent and TradeMark Office/ USPTO) referred to the composition of matter in these cells; subsequently, patents for methods used in isolation and purification of stem cells were approved as well. When a method is the subject matter of patent protection, patent protection extends to products directly obtained from this method. In case of inventions involving stem cells, the general provisions of relevant regulations apply, including those referring to patent protection of medicaments (Bouvet, 2002: 40).

\section{Conditions for stem cell patent protection}

In principle, to be patentable, every biotechnological invention must meet the same criteria as do inventions from any other technology area. Laws and legal documents, such as: the European Patent Convention (EPC), the Agreement on Trade-related aspects of Intellectual Property Rights (TRIPS), and the national Patents Act (PA), prescribe conditions of patentability of an invention but do not define the term "patent".

Unlike the Patents Act of 1995, which defines a patent as a new solution for a technical problem, the current Patents Act (2019) of the Republic of Serbia defines a patent as a right which is recognized for invention in any new technological area, provided that the patent is original, inventive (ingenious) and industrially applicable (Article $7 \mathrm{PA})^{4}$.

The European Patent Convention (EPC) includes a similar solution, according to which European patents are approved for inventions that are new, represent the result of creative work and that can be applied in the industry (Article 52 (1) EPC). ${ }^{5}$

In the USA, in order to get patent protection, an invention has to fulfill conditions prescribed by law, such as: novelty, non-obviousness, and utility. Although

3 Case 112/11, Oliver Brustle v Greenpeace e V language Europa EU, Court of Justice of the EU (2011).

4 Article 7. Zakona o patentima (Patents Act) , Sl. glasnik RS, 2019/66.

5 Article 52 (1), European Patent Convention, Official Journal EPO,1973/10. 
biotechnological inventions are considered morally controversial, there are no legally moral limitations in the patent law in the USA, unlike European patent rules (Thorstenson, 2007: 50).

Stem cells meet the condition of novelty if they are modified or isolated from the natural environment. Then, a question arises whether the isolation method is by itself sufficient in meeting the condition of novelty. If the isolation method is not sufficient, non-modified stem cells would not meet the novelty criterion but would be qualified as products of nature that cannot be patented. The prevailing understanding is that the main question of defining stem cell's patentability is whether they are technically new or they derive from the existing state of technology (Zhu, 2011: 67).

Novelty is examined by comparing submitted patent to concrete, defined, technical solutions that are explicitly chosen from the overall state of technology, which means that the novelty is "overthrown" by the existence of one document or one product from the overall state of technology that has the same characteristics as the submitted invention (Марковић, 2016: 43).

In determining the current state of technology, we can conclude from all of the above that the patent offices mostly limit the volume and content of previous technology state to the subset of technology states that are defined in relation to the field of the invention (Xiang, Lingli, Shiwen, Ning, 2003: 541). A patent can be acknowledged as an invention only in cases where the details of it were not previously published. Since institutional and personal work of researchers was until recently valued solely based on scientific work, publishing was considered more important than the attempt to provide patent protection. However, after submitting a patent, researchers can publish an invention without violating its patent protection. The research of the European Commission for Internal Market and Research shows that in most cases there is no postponement of publishing that could relate to the previous admission of the patent application; so, the practice of combining patents with publishing papers is increasingly applied ${ }^{6}$.

In cases where technical information relates to alive biological material, as a condition of such material entering the technical state, patent law prescribes deposition of the material in a competent depository institution where experts, under defined conditions, can take a sample of biological material and multiply it (Марковић, 1997: 102).

In most relevant European Union regulations, technical intervention is also a criterion for deciding whether the element isolated from the human body will

6 Zavod za intelektualnu svojinu (2017): „Bavite se istraživanjima, razmišljajte o patentima“, www.zis.gov.rs/upload/Publikacije/Lifleti/Bavite\%20se\%20istraživawem.pdf, accessed 8. 3.2017 
be considered a discovery or an invention (within the meaning of Art. 52 (1) EPC). "Isolation" and "purification" are arguments that differentiate isolated and purified materials from the natural ones. However, there are remarks on whether the concepts of "isolation" and "purification" are legal terms, i.e. that they are an artificial construction designed to draw the line between what is and what is not possible to patent. The concept of isolation was adopted by the European Patent Office (EPO) and the USPTO in European Union, by adopting the Biotechnological Directive (Article 5) while in the USA it was incorporated into legal practice.

The Biotechnological Directive ${ }^{7}$ stipulates: "1) The human body, at differentstages of its formation and development, and the simple discovery of one of its elements, including the sequence or partial sequence of a gene, cannot constitute patentable invention. 2) An element isolated from the human body or otherwise produced by means of a technical process, including the sequence or partial sequence of a gene, may constitute a patentable invention, even if the structure of that element is identical to that of a natural element." (Article $5(1,2)$ Directive).

The stated solution creates a legal area for approving patents for "elements" such as genes or stem cells, but by differentiating in vivo items and isolated components of the human body obtained by the technical intervention (Bahadur, Morrison, 2010: 68). Artificial intervention, like isolation from in vivo environment or purification from the original biological environment, is sufficient to satisfy the condition of novelty (Zhu, 2011: 68).

By isolating embryonic cell lines from an embryo in separate vessels, the condition of novelty is actually fulfilled because cultivating cells in an artificial environment can change molecular or even chromosome structure so that they could differ from the embryo out of which they were isolated (Jamil, 2016: 80).

In examining the patentability of an invention, the requirement of novelty is examined first, and then the level of innovation. In case of establishing novelty (any difference between the invention and the current state of technology), the examination of innovation level is conducted. Two very important factors are important in interpreting the innovation level: 1) an expert from the appropriate technology sector, and 2) obviousness in terms of the state of technology.

The term "expert" implies a college-educated person with a certain level of experience, a person who regularly practices some area of technology and is familiar with general knowledge in appropriate areas and of a certain date. It is assumed that such a person has access to everything related to the state of technology, especially documents from patent documentation listed in the internal report,

7 Article 5. (1)(2), Directive on the legal protection of biotechnological inventions /EC/98/44. 
that he/she has the ability to perform routine work and experiments, and that he/she has access to standard instruments to do so (Чабаркапа, Петровић, Дуњић, 2013: 156). The term "obviousness" implies the invention which does not exceed the boundaries of standard technological progress but, in a simple and logical manner, arises from the previous state of technology (Чабаркапа, et al., 2013: 157).

In the USA, the condition of "non-obviousness" was first prescribed in the U.S. Patent Act of 1952. Article 103 of the current USA patent law (U.S. Code, Title 35 -Patents $)^{8}$ prescribes that the patent for the submitted invention cannot be approved, regardless of whether the invention is not identical to published patents, if the differences between the submitted invention and the current state of technology are such that the invention examined would be obvious to the expert with ordinary experience in the field at the time when the item is invented and by using methods to which the submitted invention relates. (Article 103, U.S. Code, Title 35-Patents). During the examination of the innovation level of an invention, the basic question is whether the result is "reasonably" predictable, based on the current state of technology, that is, whether a person with ordinary experience in the area of technology can expect success. If the state of technology leads to the manufacturing of the present invention and there is a realistic expectation that the invention will occur, then the condition of innovation, i.e. non-obviousness, has not been met. When examining whether the condition of innovation related to embryonic stem cells is met, it is necessary to determine whether the method of deriving cell lines is obvious for an expert in that area. Therefore, the examination of technology must be conducted by a specialized expert who will understand all technical particularities and details of chemistry, biology, and genetics (Марковић, 2016: 51). Non-obviousness actually distinguishes an expert from an inventor. For the invention to be non-obvious to the expert, it is necessary for the inventor to manifest creativity in shaping and subjugating nature (Фишер, 2006: 62).

In European patent law, the current definition of the requirement concerning industry applicability is stated in Article 57 of the EPC, which emphasizes that an invention is industrially applicable "if it can be made or used in any kind of industry, including agriculture." The Serbian Patents Act (2019) defines the requirement of industrial applicability in the same manner. ${ }^{9}$

The term "industry" is interpreted in a broader sense, that is, as a term encompassing physical activity of a "technical" nature, i.e. the activity that belongs to

8 U.S. Code, Title 35-Patents, Art. 103 (Conditions for patentability: non-obvious subject matter),

9 Article 13, Zakon o patentima (Patent Act), Sl. glasnik RS, 66/19. 
the group of practical or useful creations, unlike aesthetic creations. The term "industry" does not imply only the mandatory use of machines or a manufacture of a certain item, but it can also encompass a certain method (e.g. the process of converting energy from one form to another) (Чабаркапа, et al. 2013: 158). Industry applicability implies the possibility of the invention application in the provision of services (Марковић, Поповић, 2015: 110).

The requirement of industry applicability in the European-continental legal system is a counterpart of the utility requirement acknowledged in the AngloSaxon legal system. In the USA law, besides the requirements of novelty and non-obviousness, the invention has to meet the requirement of utility. In addition, the invention has to meet the utility requirements stipulated in the United States Patent and Trademark Office (USPTO) Guidelines (2001). ${ }^{10}$ According to the USPTO Guidelines, in order to meet the utility requirement, the patent has to possess at least one specific, important, and credible practical usage (Спасић, 2006: 84).

The moral status of an embryo is the focal point of the conversation on stem cell research and stem cell patents. By providing a certain level of protection to an invention or patent, we face a classic moral dilemma: is it right to cause some evil in order to achieve a higher good? In the context of embryo stem cells, is it allowed to manufacture or use the existing embryos to create embryonic cell threads? The central problem is the moral status of the embryo as a source of embryonic stem cells. At the international level, the accepted opinion is that the research on embryos is ethically right if a human stands to gain out of them, without any significant risk of damage. Within this perspective, destroying embryos and extracting embryonic stem cells would be ethically unacceptable. But, if an embryo is considered only as a pile of cells that would become a complete human being only after a certain time period, then the research on embryos is allowed without any moral limitations. In-between these two complete opposite views on the embryo status, there is an array of "mixed views". There are views that early embryos should not be treated as human beings; therefore, they do not enjoy the same protection level (as humans), even though the status of an embryo changes in line with its development. For this reason, early embryos can be used for research purposes (Jochemsen, Garcia, Meir, Harris, 2005: 59).

The first moral dilemma in terms of stem cell research is the issue of the status of different types of stem cells, as well as the sources of their origin. The question is: at which moment in human development do human beings acquire the right to dignity and protection? Considering that embryonic stem cells are derived

10 US PTO Guidelines: Utility Examination Guidelines, Federal Register, Vol. 66, No. 4, 5. January, 2001, p. 1092. 
from an embryo in the blastocyst phase, the status of the blastocyst is the focal point of the conversation about embryonic stem cells.

From the scientific standpoint, the supporters of embryonic stem cell research have different reasons for distinguishing embryonic stem cells from living beings. Firstly, it is not exactly obvious when the new genes take control over the embryo; so, the zygote cannot be identified with a newborn. Embryonic stem cells have a modified status of DNA methylation that is a complete opposite of mature stem cells. For example, in female embryonic stem cells, both X chromosomes are active. During embryonic development, one $\mathrm{X}$ chromosome is inactive. Even later, when a new genetic complement is created, the zygote does not have enough information to create a human being; so, the formation of an embryo relies on factors that are not genetic information. Because of that, a zygote should not have the same moral status as a human being. In support of the claim that human life does not start with fertilization, the proponents of this stance point out that the nervous and brain systems, the heart and blood vessels are not formed in any other stage before the blastocyst (Zhu, 2011: 30).

The biological process begins with the fertilization of the cell, which then starts to divide. During the first few divisions, cells identical to each other are being created. It is the blastocyst stage, during which 100 identical cells can be created; these cells are totipotent, meaning that they have the capacity to form a new embryo, placenta, or umbilical cord. The period of totipotency is limited to 3-4 days after conception, after which they begin to differ; so, some of them make up the umbilical cord and placenta, and others make up the body of the fetus in the internal cell mass of the blastocyst. Then, cells become pluripotent, but still have an unlimited capacity for regeneration in laboratory environments (Дакић, 2016: 234).

Considering that they are not derived from an embryo in the totipotency phase, stem cell and embryonic cell threads are morally acceptable because there is no possibility of them converting into an embryo and later into a human being. In discussing the potential utility in stem cell research, the European Group on Ethics in Science and New Technologies (EGE) also pointed out that the research of pluripotent embryonic stem cells should be allowed while taking every necessary precaution. Thus, the EGE (2002) suggested prescribing strict rules so that research could be conducted mainly on "overabundant" embryos from artificial insemination clinics ${ }^{11}$.

11 The European Group on Ethics in Science and New Technologies (EGE), Opinion No. 16 on the ethical aspects of patenting inventions involving human stem cells, 7 May 2002, EGE, European Commission, 2002. 


\section{Conclusion}

Unlike the Anglo-American legal system which approved stem cell legal protection from the beginning, the European-continental legal system excluded stem cells from patent protection. The essential difference between the two legal systems is reflected in the fact that most European patent laws include a "moral clause" which enables competent authorities to refuse a patent on a moral basis. On the other hand, in the Anglo-American legal system, moral evaluation is not formalized but researchers mainly focus on the questions of novelty, nonobviousness, and utility (industrial applicability).

The opponents of stem cell patents point out that, in order to derive cell threads from embryonic stem cells, the embryo has to be destroyed, which constitutes a violation of human dignity. The legal theory does not define human dignity, nor the moral status of an embryo. In terms of stem cell patent protection, there is no moral consensus in Europe. The moral status of embryos and stem cells is a very complex question, primarily because an embryo (in spite of not having all characteristics of a person) eventually becomes a human being. It raises an issue of whether it is justified to destroy an embryo and derive stem cells from it. It should be pointed out that research is mainly conducted on "overabundant" embryos, created by the in vitro fertilization method in the artificial insemination clinics. It raises another issue: is it more moral to dispose of such an embryo, or to use it for research purposes? The observance of moral standards can be achieved within the limits of patent law and ethical evaluation conducted by the competent authority, both of which speak in favor of stem cell patents.

\section{References}

Bahadur, G.; Morrison, M. (2010). Patenting human pluripotent cells: balancing commercial, academic and ethical interests. Human Reproduction 25(I). Oxford University Press. 14-21.

Bouvet, Ph. (2002). Patentability of inventions involving human stem cells in Europe. Journal of Commercial Biotechnology 9 (1). 40-48.

Дакић, Д. (2016). Изазови европског регионалног законодавства на пољу заштите живота: Крагујевац: Правни факултет Универзитета у Крагујевцу.

Фишер, С. (2006). Правна природа патента као субјективног права. Нови Сад: Правни факултет Универзитета у Новом Саду.

Jamil, A. (2016). Patent framework for the human stem cells in Europe and USA: innovation, ethics, and access to therapy. Doctoral Degree in Law, Science and Technology (LAST-JD), CIRSFID, University of Bologna, Italy. 
Jochemsen, H.; Garcia, E.; Meir, A.; Harris, R. (2005). Human Stem Cells, Source of Hope and Controversy. Bioethics Press. Chicago and London.

Laurie, G. (2004). Patenting stem cells of human origin. European Intellectual Property Review. 26 (2). 59-66.

Mitalipov, Sh.; Wolf, D.; Li, V. (2009) . Totipotency, pluripotency and nuclear reprogramming. National Institutes of Health, Advances in Biochemical Engineering Biotechnology. 114 (185-199).

Марковић, С. (1997). Патентно право. Београд.

Марковић, С. (2016). Да ли је оквир патентног права постао неодговарајући за проналаске лекова. Актуелна питања права интелектуалне својине и права конкуренције: поглед са Балкана. Београд. 29-53.

Марковић, С. Поповић, Д. (2015). Право интелектуалне својине. Београд.

Radonjanin A. (2007). Patentability of biotechnology. Европски правник.

Спасић, В. (2006). Патен тирање производа биотехнологије. Зборник радова Правниог факултета у Нишу. XLVII.77-95.

Thorstenson, A. (2007). Patentability of Human Embryonic Stem Cells, Finding the Balance between the Moral Hazard in Europe and the Wide Scope in the US, Faculty of Law, University of Lund.

Xiang, L. Lingli, D. Shiwen, O. Ning, Zh. (2013). A comparative analysis of the inventive step standard in the EPO, SIPO and USPTO". Journal of Intellectual Property Law \& Practice. 8 (7). 539-545.

Zhu, H. (2011). A Comparative Study on Human Embryonic Stem Cell Patent Law In the United States. The European Patent Organization and China, School of Law: University of Kansas

Чабаркапа, О., Петровић, Д., Дуњић, М. (2013). Услови патентибилности проналазака. Војно технички гласник. LXI.1. 146- 161.

Legal documents

Directive 98/44/EC of the European Parliament and of the Council of 6 July 1998 on the legal protection of biotechnological inventions (EC/98/44); https:// wipolex.wipo.int/en/text/126957

European Patent Convention, Official Journal EPO, 1973/10, revised by the Act revising the EPC of 29 November 2000, European Patent Convention, EPO, April 2018č https://www.epo.org/law-practice/legal-texts/html/epc/2016/e/EPC_ conv_20180401_en_20181012.pdf 
The European Group on Ethics in Science and New Technologies, Opinion on the ethical aspects of patenting inventions involving human stem cells, Opinion No. 16, 7 May 2002, EGE, European Commission, published 28.06. 2002, available at https://op.europa.eu/en/publication-detail/-/publication/687b0402-32b84b1a-905e-b7885d2a3eac

Zakon o patentima (Patent Act), Službeni glasnik Republike Srbije, 66/19.

U.S. Code, Title 35-Patents, Art. 103 (Conditions for patentability: non-obvious subject matter), United States Code, 2011 Edition, Government Publishing Office, Washington D.C.; https://www.govinfo.gov/content/pkg/USCODE-2011-title35/ html/USCODE-2011-title35.htm

US PTO Guidelines: Utility Examination Guidelines, Federal Register, Vol.66/ No.4, 5.Jan.2001, p.1092; https://www.uspto.gov/sites/default/files/web/offices/com/sol/notices/utilexmguide.pdf

Online resources

Deutsche Welle (DW), 22.10.2015, Regenerativna medicina-nada za mnoge (Regenerative medicine), by Gudrun Hajze, https://www.dw.com/sr/regenerativna-medicina-nada-za-mnoge/a-18799514, accessed 24.06.2020.

Seracell.rs (2020) .Tipovi matičnih ćelija (Types of stem cells), https://www. seracell.rs/maticne-celije/tipovi-maticnih-celija/, accessed 25.08.2020.

Zavod za intelektualnu svojinu (2017):Bavite se istraživanjima, razmišljajte o patentima, www.zis.gov.rs/upload/Publikacije/Lifleti/Bavite\%20se\%20istraživawem.pdf, 8. 3.2017 


\title{
Др Гордана Дамјановић, \\ Доцент Правни факултета, \\ Универзитет у Приштини са привременим \\ седиштем у Косовској Митровищи
}

\section{ЗА И ПРОТИВ ПАТЕНТИРАҢА МАТИЧНИХ КЕЛИЈА}

\begin{abstract}
Резиме
Еволуција и трансформација истраживања у области биотехнологије одражава се и на патентна правила. Најпре је одобрено патентирање гена, да би даљи развој биотехнологије, али и притисак мултинационалних биотехнолошких компанија иницирао прописивање патентне заштите матичних ћелија у појединим правним системима. Истраживања би требало да обезбеде боље разумевање диференцијацие и развоја матичних ћелија, са могућим последицама за излечење до сада неизлечивих болести, али и да омогуће нове начине за истраживања фундаменталних питања у биологији, као што је механизам за раст ћелија. Истраживачи, али највише биотехнолошке компаније, залажу се због тога за обезбеђивање монопола над резултатима својих истраживања. Такав монопол обезбеђује патент. Поред тога што је постигнут изузетан напредаку истраживању матичних ћелија, многи аспекти коришћења, посебно ембрионалних ћелија нису били у потпуности разумљиви и јасни. Успешна примена производа који користе неки дериват матичних ћелија са једне стране и моралне дилеме, које се односе првенствено на ембрионалне матичне ћелије са друге стране, резултирале су у расправи која је утицала на многа правна подручја, попут патентног права. Такви морално изазовни производи су проузроковали велику забринутост у САД и ЕУ. Међутим, ова два ентитета су на различите начине покушала да реше проблем. Различити погледи на право, етику и ембрионе, утицали су и на различита становишта у погледу патентне заштите матичних ћелија.
\end{abstract}

Кључне речи: биотехнологија, проналасци, патенти, гени, матичне ћелије. 